DOI https://doi.org/10.30525/978-9934-588-37-2.1.15

\title{
THEORETICAL ASPECTS OF PERFECTIONISM INFLUENCE ON THE PERSONALITY
}

\section{Zavada T. Yu.}

\section{INTRODUCTION}

Since ancient times to the present, people have always been interested in the problems of exploring their own inner world, discovering their resources, exploiting inner qualities. At whatever stage of self-improvement a person is, he/she directs his/her efforts to move forward. Human multiplies what is relevant to him/her. And, practically, any sphere is inexhaustible.

The modern social environment puts high demands on the functioning of human performance. the cultivation of success, the provision of high material wealth, and prestigious social status are an important component among the values of modern society. The cult of perfection is typical of almost all Western cultures.

The tendency to self-perfection is revealed through the concepts of "selfimprovement", "self-fulfilment", "self-actualization". Self-actualization (as the need for "self" actualization) is at the forefront of humanistic psychology. By revealing different aspects of own Self, one thus provides one with the effective functioning in the society, internal harmony, subjective well-being.

However, the desire for self-improovement, the acquisition of new knowledge and experience, the realization of one's own potential, can be idealized, the desire to acquire "obsessive" behavior in the fight for the best, the most perfect, to transform in the pursuit of constant compliance with the highest norms and standards and the need to maintain this image. This phenomenon is already revealed through the concept of perfectionism.

For a long time, one of the most debatable questions was whether to consider perfectionism as a pronounced manifestation of a healthy desire for self-improvement or an obsessive possession with existing perfection?

In the theoretical field, there is a considerable number of systematic and generalized scientific views on the structure of perfectionism, theoretical models and typologies developed, however, discussions on the ambivalence of the nature of this psychological phenomenon are still ongoing.

On the one hand, perfectionism is a socially acceptable phenomenon, modern social conditions and realities are actively promoting it. Compliance with high standards, a variety of achievements are approved and cultivated 
by modern society, any activity helps in the best way to get the perfectionists recognition from the environment, situationally raise self-esteem, be active, innovate, build standards of development. This behavior is prosocial and desirable. However, on the other hand, the belief that everything should be perfected, be "the best", meet the highest standards - provokes a number of dysfunctional manifestations that negatively affect the psychological wellbeing of the individual - fear of mistakes, criticism; anxiety; doubts about their own actions; inability to get pleasure from the results of the activity, etc. So such features more disorganize than promote harmonious selfdevelopment of the individual.

\section{Theoretical approaches towards perfectionism conception as a psychological phenomenon}

In humanistic psychology, the pursuit of self-improvement is seen as identical to the concepts of "tendency to self-actualization" (C. Rogers), "need for self-actualization" (A. Maslow), "raison d'ertre" (V. Frankl); self-fulfilment, supreme values of being, transcendental experience.

Self-actualization is an internal desire of a person to fully reveal his or her abilities, skills, etc. The essence of self-fulfilment lies not in the full realization of one's potential (which is practically impossible), but only in those parties that are most significant to man.

Self-actualization issues are covered in the works of such scholars as A. Maslow, R. May, C. Rogers, V. Frankl, B. Ananyeva, L. Vygotskiy, G. Kostyuk, O. Leontyev, S. Maksimenko, S Rubinshtein, T. Titarenko and others.

This concept was most fully developed by Abraham Maslow. He believed that self-actualization was the highest need of the individual (according to the hierarchy of needs developed by him), which consisted in the continuous realization by the person throughout his life of his/her endogenous capacities; congruently to one's inner nature, "human should be suchlike he/she can be"1. A. Maslow notes that human nature is not ideal. And, even, to "self-actualized" people, selfishness, depression, anger, fear, etc. are inherent. This is an important clarification, because self-actualization is a powerful factor that motivates the individual to reveal the inner sides of his/her Self, however, it is a peak that a person will never be able to reach.

When it comes to perfectionism, in a broad sense, it is the pursuit of perfection, and therefore the perfectionist is a person who wants to be better in all aspects of his or her life.

Despite the fact that the phenomenon of perfectionism began to be studied in psychology from the 60's of the twentieth century, separate

\footnotetext{
${ }^{1}$ Maslow A. Motivation and personality. New York : Harper and Row, 1987.
} 
scientific explorations of this problem can be found in the writings of psychoanalytic direction in the 30's of the twentieth century.

S. Freud laid the foundations for the pursuit of perfection through the concept of the "ego ideal", the emergence of which is connected with narcissism. What a person sets as an ideal is a substitute for the narcissism lost in childhood when the child sees the ideal in himself/herself ${ }^{2}$. According to C. Jung, the pursuit of perfection is an inherent property of the individual, which determines the presence in its structure of self, and is also one of the most powerful roots of civilization ${ }^{3}$.

In the psychoanalytic tradition, perfectionism is considered (through the prism of the structural model of the functioning of the psyche) as unsuccessful attempts by Ego to meet the unrealistic infantile demands of omnipotence and supreme achievements of Superego (Ch. Raikroft, D. Aike, A. Holder, D. Kalsher, F. Taison, R. Taison). In the context of ideas about the narcissistic personality, the pursuit of unattainable ideals is understood as a destructive strategy for compensation for the defects of the "I", the support of one's own idealized image, the non-realization of which contributes to the experience of the "narcissistic collapse" (S. Akhtar, F. Rhodewalt, P. Sorrow, O. Kernberg, H. Kohut, N. McWilliams, G. Rozenfeld, O. Sokolova).

In modern psychoanalysis, perfectionism is often seen as a defense against the experience of "paralyzing" shame (B. Kilborn, E. Rehardt, and P. Iconen).

In general, in psychoanalytic writings, the problem of perfectionism is interrelated with the problem of destructiveness, which covers all spheres of human life and manifests in the violation of self-identity, distortion of objective representations, negative-hostile attitude to oneself and others, severe emotional experiences, disorders of cognitive functioning and affective control.

The development of ideas of perfectionism in psychology is greatly expanded by social psychoanalysts, in particular, A. Adler and K. Horney. A. Adler does not use the term "perfectionism", however, the basic concept of his "individual psychology" - "the desire for excellence" has much in common with him. The achievement of the ideal, the superiority over others, is, according to A. Adler, an integral, innate part of life. By feeling own inferiority, one begins the long struggle of man for the achievement of superiority over the environment, as well as the desire for perfection and flawlessness, which is the main motivating force in human life $^{4}$.

\footnotetext{
${ }^{2}$ Freud S. A general intodaction of psychoanalysis. New York : Boni and Liveright, 1920.

${ }^{3}$ Jung, C.G. On the Nature of the Psyche. London : Ark Paperbacks, 1947.

${ }^{4}$ Adler A. Understanding Human Nature. Oxford : Oneworld, 1927 (reprinted 1992).
} 
K. Horney, emphasizes the neurotic need for excellence within the development of her neuroses theory. The name itself defines the resemblance to perfectionism. The need for excellence is characterized by constant reflection and self-blame for possible failure, fear of finding fault, fear of criticism or accusation, feeling of superiority over others, an obsessive pursuit of excellence ${ }^{5}$.

$\mathrm{K}$. Horney believes that the notion of a real desire for self-improvement should be distinguished from the pseudo-need to "appear perfect" to yourself and other people. The researcher notes that the driving force behind neurotics is not the need for improvement, but only its visibility. This is not a goal that one strives for, but a fixed idea that he/she worships. The idealized image becomes a barrier to growth because it denies shortconmings ${ }^{6}$.

In the 1960s, K. Horney's ideas were developed in the work of M. Hollander, who for the first time singled out the term 'perfectionism' and defined it as "presenting higher requirements for performance of activity than circumstances require" . D. Burns, a representative of the cognitive direction, defined perfectionism as a special set of cognitions based on a tendency to set unrealistically high standards, as well as a compulsive pursuit of impossible goals and to estimate one's value solely in terms of achievement and productivity. The scientist adds to the basic parameter of perfectionism - the tendency to set extremely high standards - adds such cognitive parameters as "thinking in terms of all or nothing" and "selective concentration on present and past mistakes" .

In the subsequent studies, the structure of perfectionism became more complicated. Thus, R. Frost ${ }^{9}$ in the structure of perfectionism identified the following parameters: 1. Concern over Mistakes; 2. Doubts about Actions; 3. Personal Standards; 4. Parental Expectations; 5. Parental Criticism; 6. Organization.

P. Hewitt and J. Flett also considered perfectionism as a complex structure, and identified its following components: 1. Self-oriented perfectionism; 2. Other-oriented perfectionism; 3. Socially prescribed perfectionism $^{10}$.

\footnotetext{
${ }^{5}$ Horney, K. The neurotic personality of our time. New Haven, CT : Yale Univesity Press, 1999.

${ }^{6}$ Horney K. Our inner conflicts. New York : Norton, 1945.

${ }^{7}$ Hollender M. Perfectionism. Comprehensive Psychiatry. V. 6. 1965. P. 94-103.

${ }^{8}$ Burns D. The perfectionist's script for self-defeat. Psychology Today.1980. P. 34-52.

9 Frost R., Marten P., Lahart C., Rosenblate R. Cognitive Therapy and Research. 1990. № 14 (5). P. 449-468.

${ }^{10}$ Hewitt P., Flett G. Perfectionism in the Self and Social context: conceptualization, assessement and association with psychopathology, Journal of Personality and Social Psychology. 1991. V. 60. № 3. P. 456-470.
} 
N. Garanyan ${ }^{11}$ define perfectionism as a personal factor, which is a complex psychological construct and combines the following components: 1) extremely high standards and aspirations in the expected results of activity; 2) impairment of social cognition (attribution of excessively high expectations to people); 3) personalization associated with the constant comparison of oneself with others; 4) polarized thinking, on the principle of "all or nothing"; 5) fixation on negative information about the results of its activity.

I. Hulias notes that "perfectionist attitudes evolve as a result of consolidating the motivation of achieving as a dialectical unity of aspirations to affiliation and power at the level of a stable personality trait (perfectionism), manifested in the daily willingness to strive for success and gain success in the pursuit of success" $"$.

L. Danilevich notes that perfectionism is a multidimensional and hierarchically organized personality trait containing the following components: high standards, organization and dysfunctional perfectionism $^{13}$. The author considers high standards and organization as aspects of functional perfectionism. While researching the problem of academically gifted individuals (on a student sample), the researcher indicates that dysfunctional perfectionism (delaying actions, disorganization) adversely affects the productivity of learning and psychological well-being of the individual. Conversely, the combination of high organization, moderately high standards, and low levels of manifestation of the dysfunctional components of perfectionism promotes academic talent. The fact that students did not show academic talent without signs of perfectionism as such was of the interest.

O. Loza identifies two basic constructs of perfectionism: "high personal standards", reflecting the desire to be perfect and "polarization of thinking", which characterizes the rigid attitude to mistakes and can be directed at themselves or others. Based on such a model, the author distinguishes four forms (types) of perfectionism ${ }^{14}: 1$ ) hyperperfectionism (excessive) - characterized by very high rates of standards and polarization; 2) constructive (moderate) - characterized by high rates of standards,

${ }^{11}$ Гаранян Н.Г. Психологические модели перфекционизма. Вопросы психологии. 2009. № 5. С. 74-83.

12 Гуляс I.A. Перфекціоністські настанови як чинник професійної готовності майбутніх практичних психологів : автореф. дис. ... канд. псих. наук. ІваноФранківськ, 2007. 21 с.

Данилевич Л.А. Перфекціонізм як особистий чинник академічної обдарованості студентів : дис. ... канд. псих. наук. Київ, 2010. 240 с.

Лоза О.О. Особливості перфекціонізму як особистісної риси державних службовців : дис. ... канд. псих. наук. Київ, 2015. 205 с. 
however, low polarizations of thinking; 3 . destructive (insufficient) characterized by low expression of standards and, at the same time, high polarization of thinking; 4. hypoperfectionism (absent) - both components of perfectionism have low indicators, which can testify to its practical absence.

So, to sum up, we can outline that there is a number of ambiguities in the study of psychological science in the study of perfectionism. Perfectionism reflects the desire of the individual for perfection; self-representation and, in general, the environment - extremely high requirements and unrealistic standards. Thus, perfectionism includes not only a personal style that defines the desired limits of achievement, but also a socially-oriented style that reflects the importance of the sociocultural aspect of perfectionism.

\section{Place and importance of perfectionism in human life.}

\section{Common and different in perfectionism and pedantry}

Some researchers consider perfectionism as a factor that positively influences personality formation (O. Artemyeva, S. Volkova, K. Dembrovsky, I. Malkina-Pykh, O. Savenkov, H. Chepurna), others - as a dysfunctional feature (D. Bern, M. Hallender, R. Shafran, O. Sokolova, N. Garanyan, A. Holmogorova, and T. Yudeeva). Depending on the influence on a person, it is customary to distinguish between normal and pathological (or positive and negative, functional and dysfunctional, healthy and painful, normal and neurotic) perfectionism.

Firstly, perfectionism was considered only as a pathological addiction. D. Hamachek was first who proposed to distinguish between perfectionism in its two manifestations: normal (adaptive) and neurotic (maladaptive) ${ }^{15}$. Individuals with adaptive perfectionism set high standards for themselves, but they are not pedantic and flexible. They can adapt their standards to the current situation, that is, they are more adaptive than neurotic perfectionists, who set unrealistic demands on their activities and do not make mistakes in it.

W. Parker distinguished between healthy perfectionism associated with honesty (the Big Five model) and unhealthy, associated with low selfesteem $^{16}$. Subsequently, the scientist together with K. Adkins distinguish between active and passive perfectionism. Active perfectionism - stimulates to achievements, passive - because of excessive concern for mistakes, doubts, creates obstacles to activity. R. Slainy, K. Rice, and J. Ashby ${ }^{17}$

${ }^{15}$ Hamachek D. Psychodynamics of normal and neurotic perfectionism. Psychology. 1978. № 15. P. 27-33.

${ }_{16}$ Parker W., Adkins K. Perfectionism and the gifted. Roeper Review. 1995. V. 17. № 3. P. 173-176.

${ }^{17}$ Rice K., Ashby J., Slaney R. Self-esteem as a mediator between perfectionism and depression: A structural equation analysis. Journal of Counseling Psychology. 1998. V. 45. № 3. P. 304-314. 
initially identified adaptive and maladaptive perfectionism, but afterwards distinguished positive and negative perfectionism (depending on the type of reinforcement).

N. Garanyan distinguishes between healthy and pathological perfectionism according to the following criteria: motivational, cognitive, affective, behavioral. A. Holmogorova, N. Garanyan also distinguish two forms of pathological perfectionism - narcissistic and obsessivecompulsive $^{18}$. Narcissistic perfectionism is dominated by motivation to achieve excellence, gain approval and admiration to the detriment of all other motives. He is the core of the individual, so abandoning him is identical with abandoning his own self. The main feature of narcissistic perfectionism is the lack of interest in the content of the activity, pathological fixation on its results and attention from the environment. One prevails in the motivational sphere, overvalued motive.

With obsessive-compulsive perfectionism (a simpler form), the idealized image I do not supersede all other human motives and interests, as in narcissistic ones. Such people are interested not only in the result but also in the activity itself; the focus on achievement is about the value of the work being done, not just the compelling need to excite.

O. Kashina also distinguishes between adaptive and maladaptive forms of perfectionism, based on research.

As A. Zolotaryova notes, in general, "normal" perfectionism is a harmonious desire of the person to perfection, which does not conflict with other human motives, and "pathological" - the pursuit of perfection in any way, including harm to the health, psychological well-being and other spheres of life ${ }^{19}$.

An important issue in the problem of perfectionism is its place in the structure of personality. In particular, N. Garanyan raises the question of whether perfectionism is a feature of a certain type of personality, or can it be in the structure of different personality types? No less important is the question of the effect of perfectionism on human. Some researchers emphasize the positive aspects of this phenomenon, others - on the contrary.

Scientists have found a correlation between perfectionism and dysfunctional traits of different personality types. The complex of qualities inherent in perfectionism are included in the structure of certain constitutional and personality types.

18 Холмогорова А., Гаранян Н. Нарцисизм, перфекционизм и депрессия. Московский психотерапевтический журнал. 2004. № 4. С. 18-35.

19 Золотарева А.А. Диагностика индивидуальных различий перфекционизма личности : автореф. дис. ... канд. псих. наук : 19.00.01. Москва, 2012. 25 с. 
Thus, K. Schneider describes "depressive psychopathy" as distinguishing such traits as modesty, anxiety, decision-making disorder, diffidence in own efforts to work hard, lack of satisfaction from success. Describing depressive and cycloid psychopathy, P. Gannushkin notes that individuals of these types often experience guilt and reproach over past mistakes. Such type of people is difficult to work with, as they often find deficiencies in the work being done, making it difficult to start new activities ${ }^{20}$.

M. Shimoda describes statotimia - a premormid personal trait that is characteristic of people with monopolar depression ${ }^{21}$. The author attributes pedomatic traits, high self-exactingness, constant dissatisfaction with oneself, responsibility, persistence, accuracy.

$\mathrm{H}$. Tellenbach described the premorbid type of the depressive personality Typus melancholicus. The author notes the following features of a melancholic type: addiction to order, scrupulousness, fairness, increased responsibility, work dependence ("weekend neurosis" - inability to rest on weekends) $)^{22}$. As an important feature of depressive personalities, H. Tellenbach highlights - a high level of aspiration.

The results of scientific studies that point to the correlation of perfectionism with various psychological disharmonies should be considered.

Researchers singles out characteristic features of perfectionism that are similar to narcissistic personality. In particular, in narcissism, the violations of the motivational sphere are singled out. Personality can be successful in professional activity, but the motivation for professional activity is the desire for rapid success, satisfaction of ambition, universal enthusiasm. The same features (with some specifications) are inherent in perfectionists. In interpersonal relationships, narcissistic personalities are prone to over idealization and, as a consequence, devaluation of relationships, which can also be traced to perfectionists. Another narcissistic feature similar to perfectionism is the intolerance of criticism that threatens the self-ideal and frustrates the I-real.

Perfectionism also has a similarity with neurotic disorders. Perfectionists have neurotic ways of realizing the need for love and approval (getting the love of others through trying to become perfect), in domination (striving for increasing perfection with a combination of self-doubt), in universal recognition (on which self-esteem depends). O. Sokolova notes that

${ }^{20}$ Ганнушкин П.Б. Клиника психопатий, их статика, динамика, систематика. Москва : НГМА, 1998. 122 с.

${ }^{21}$ Shimoda M. Uber den pramorbiden Charakter des manisch-depressiven Irreseins. Psychiat. Neurol. Jap. 1941. № 45. P. 101-102.

${ }_{22}$ Tellenbach H. Melancholie. Problemgeschichte Endogenitat Typologie Pathogenese Klinik. New York : Springer-Verlag Berlin-Heidelberg, 1983. 201 p. 
contradictory aspirations ingrain persons with neurotic disorders the (the desire to dominate and the need to refuse it for the sake of acceptance by others), which are a factor in experiencing the inability to change their own $\operatorname{lives}^{23}$. The same features are characteristic of persons with dysfunctional perfectionism.

In general, the number of researches is growing to date, confirming the correlation between perfectionism and depression.

D. Burn hypothesized that perfectionists are particularly prone to depression $^{24}$. S. Blatt described the "introjective" depression, which is characterized by constant self-criticism, focus on problems of attaining and experiencing a constant sense of guilt ${ }^{25}$. R. Frost has examined that perfectionism is more related to depression of self-criticism than to dependence depression ${ }^{26}$. A. Beck in the practice of cognitive psychotherapy also received confirmation of the interrelation between depression and perfectionism, and based on it two personal constructs were singled out that determine the tendency to depression - sociotropic and autonomous types. The sociotropic type is focused on the problems of attachment, dependence, the autonomous type - on the problems of independent functioning, achievements, successes and failures.

N. Garanyan, examining the problem of perfectionism as a factor of depressive and anxiety disorders, concludes that patients with depressive and anxiety disorders, compared with those from the control group, are characterized by higher rates for all parameters of perfectionism. According to the research of $\mathrm{T}$. Yudeeva ${ }^{27}$, perfectionism is a relatively stable personality trait of patients with depression (both psychogenic and endogenous).

There are a number of studies proving the relationship of perfectionism with eating disorders, including anorexia and bulimia.

In his review of empirical studies of perfectionism and mental disorders, N. Garanyan describes a cognitive model of social phobia developed by American researchers. The theory essence is that, consequently the interaction of genetic factors and specific early experience, a special sensitivity to social situations is formed, which causes social contacts to be

${ }^{23}$ Соколова Е.Т. Психология нарциссизма. Москва : «Психология», 2001. 90 с.

${ }^{24}$ Burns D. The feeling good handbook. New York : William Morrow and Company, 1989. $121 \mathrm{p}$.

25 Blatt S.J. The destructiveness of perfectionism. American Psychologist. 1995. V. 50. P. 1003-1020.

${ }^{26}$ Frost R. Reactions to mistakes among subjects high and low in perfectionistic concern over mistakes. Cognitive Therapy and Research. 1995. V. 19. P. 195-205.

27 Юдеева Т.Ю. Перфекционизм как личностный фактор депрессивных и тревожных расстройств : дис. ... канд. псих. наук. Москва, 2007. 275 с. 
considered as threatening. As a result, there is social anxiety and escape behavior. Many people with social fears are adhere to a creed that social situations are dangerous, and they are convinced that social danger can be overcome by means of perfect social behavior.

In popular science literature, often perfectionism is identified with pedantry - the desire to do everything accurately, meticulously, in time, it would seem - is perfect. However, these concepts are not identical, although they may be complementary.

Based on the research achievements of scientists on the problems of pedantry (K. Lernhard, P. Hannushkin, H. Kaplan, B. Sedok, P. Volkov, V.Zhmurov, V. Bleicher, I. Kruk) and perfectionism (D. Hamachek, R. Frost, J. Flett, P. Hewitt, D. Bern, S. Blatt, R. Shafran, L. Danilevich, N. Garanyan, A. Kholmogorova, O. Kashina, T. Yudeeva), their common and distinguishing features can be distinguished as follows.

First, consider the differences between pedantry and perfectionism:

1. For a pedantic personality, form is more important than content. The main thing is to clearly follow the rules, regulations, instructions, maintain the usual order. Pettiness, neatness is an inner need of the individual for pedantry to put everything into shape in order to avoid anxiety. These character traits appear whether or not people like it.

For perfectionists, form is not as important as for pedants, but its value is not completely offset. Perfectionists are more fixed on the content, or, more precisely, on the result, ideas. However, if they do responsible, important work that needs to be appreciated by other people, then the perfectionist will exhibit excessive scrupulousness, focusing on small and sometimes not very important details. Thus, through pedantry, perfectionists try to avoid failure and criticism. Having fear of making mistakes, the perfectionist tries to do the job as accurately and correctly as possible.

1. Perfectionists try to reach the ideal in substantial affairs, pedants - in small ones. For example, a perfectionist wants his/her book to be written flawlessly, or to make perfect repairs, it is important for the pedant to have the documents kept correctly and without corrections.

2. The perfectionist's assessment of the results of his/her own activity depends on external factors: the higher the praise or recognition of significant people, the more satisfaction he/she gets from the result, and the higher his/her self-esteem is. Pedants also evaluate their work in accordance with their own (internal) beliefs, positions.

3. Pedants are more conservative than perfectionists. If it is important for the perfectionist to go ahead and achieve high results (for the sake of accepting one's own self), then it is more important for pedants to keep things organized and stability at the level at which they are.

The following features are common for perfectionism and pedantry: 
1. Increased level of anxiety. The connection of perfectionism with anxiety is described in the works of J. Flett, P. Hewitt, D. Bern, S. Blatt, R. Shafran, L. Danilevich, N. Garanyan, A. Kholmogorova, O. Kashina, T. Yudeeva and etc. Pedantry and perfectionism are both based on internal conflict, which causes a higher level of anxiety.

2. Rigidity, inflexibility. If strong anxiety is fundamental in person's personality, then over time, the person develops certain strategies of behavior, thinking, response, which helped to "weaken" it. Because of the formed behavioral, emotional, cognitive strategies, it is difficult for pedants and perfectionists to be flexible in different situations, to try new ways of solving problems (A. Zolotaryova, N. Garanyan, A. Kholmogorova).

3. Long-term experience of traumatic situations. Perfectionism and pedantry implies the obsessiveness, the fixity of the individual on his/her own mistakes (D. Hamachek, J. Flett, P. Hewitt, S. Blatt, S. Stepanov, A. Dadanko, N. Garanyan, A. Kholmogorova, O. Kashina, T. Yudeeva).

4. Exaggerated honesty. Pedants and perfectionists make a lot of effort to ensure the perfect performance.

5. Doubts about the correctness of their actions. It is important for students to check several times whether they have switched off the light, gas, or properly sealed the envelope. Perfectionists are also unsure of the correctness of their results, because other people do not evaluate them. Therefore, their doubts relate to meeting the expectations of the environment.

R. Shafran and V. Mansel consider that perfectionism is a risk factor in obsessive-compulsive disorder ${ }^{28}$. As with obsessive-compulsive disorder, so with perfectionism, individuals have doubts about the correctness of their own actions. However, N. Garanyan specifies that the questions of the scale of "Doubts in own actions" of the multidimensional questionnaire of perfectionism of Frost, are taken from the diagnostic toolbox of obsessivecompulsive disorder. This means that the "self-doubt" subscale measures the signs of obsessive-compulsive disorder, which, in turn, is regarded by Frost as a sign of perfectionism. This situation makes it difficult to understand the structure of perfectionism.

T. Beskova ${ }^{29}$, exploring the features of the relationship between perfectionism and ways of responding to the successes or non-successes of others, proves that the higher the level of perfectionism, the more intensely the subject responds to other people's preferences, and in most cases the ways of such reaction are negative (immoral).

${ }^{28}$ Shafran R., Mansell W. Perfectionism and psychopathology: a review of research and treatment. Clinical Psychology Review. 2001. № 21. P. 879-903.

29 Бескова Т.В. Взаимосвязь перфекционизма со способами реагирования на успех и неудачу другого. Современные проблемы науки и образования. 2012. 
N. Garanyan, D. Andrusenko, I. Hlomov, in the study of emotional maladaptation and escape behavior in students with different levels of perfectionism, found that the higher the level of perfectionism, the higher the level of emotional maladaptation (depression, suicidal ideation, social suicidal ideation, anxiety), as well as various forms of escape behavior (procrastination) $)^{30}$.

P. Tsygankova considers perfectionism a fundamental component of selfdestructiveness $^{31}$. In particular, a correlation between perfectionism and: cognitive dysfunctions (low cognitive differentiation, lack of internal selfassessment criteria); emotional and regulatory disorders (general emotional distress, lack of skills to verbalize emotions and feelings, instability of selfesteem, lack of constructive strategies for dealing with stress); communicative ill-being (dissatisfaction with communication, the presence of unconscious conflicts between opposing attitudes and aspirations).

The positive aspects of perfectionism include moral talent (K. Dabrovski, T. Piechovsky). Researchers emphasize on such positive aspects of perfectionism as independence in judgments, non-conformism, responsibility, altruism.

V. Paramonova, studying the problem of adaptive perfectionism, observes that, as a rule, the degree of satisfaction with the results of activity depends on the intensit of the efforts that a person makes to achieve this goal $l^{32}$.

O. Savenkov views perfectionism as an integral part of the gifted personality ${ }^{33}$. According to the author, perfectionism is the desire of a person to perform one or another activity in the best way, even in small matters. The author believes that such quality of personality manifests itself in childhood, when the child can not enjoy their activities until it reaches the maximum result (intellectual, aesthetic, moral, etc.). As a consequence, she develops a constant dissatisfaction with his/her own activities, which reflects on the self-esteem of a person, and can be a cause of neurotic disorders and depression. Excessive perfectionism paralyzes the will of human, inhibits the possibility of work completion.

Therefore, the value of perfectionism in the life of the individual is rather ambiguous. Actually, taken into account the uncertainty and ambivalence

30 Гаранян Н., Андрусенко Д., Хломов И. Перфекционизм как фактор студенческой дезадаптации. Психологическая наука и образование. 2009. № 1. C. $72-82$.

${ }^{31}$ Цыганкова П.В. Взаимосвязь перфекционизма с особенностями самосознания при аутодеструктивном поведении. Вестник Московского государственного областного университета. Серия «Психологические науки». 2010. № 2. С. 28-32.

32 Парамонова В.В. Высшие устремления личности: перфекционизм как патологический феномен. Развитие личности. 2009. № 1. С. 64-78.

33 Савенков А.И. Путь к одаренности: исследовательское поведение дошкольников. Санкт-Петербург : Питер, 2004. 272 с. 
that exists, scientists have decided to divide perfectionism into positive and negative. However, the analysis of types of perfectionism indicates that the manifestations of "positive" perfectionism are identified with the manifestations of self-actualized personality (criteria identified by A. Maslow). Let us consider and analyze them in more detail (Table 1).

Table 1

\section{Comparative analysis of criteria of self-actualized persons} (according to A. Maslow) and "normal" perfectionism

\begin{tabular}{|c|c|}
\hline $\begin{array}{c}\text { Criteria for self- } \\
\text { actualized personalities } \\
\text { by A. Maslow }\end{array}$ & $\begin{array}{l}\text { Criteria for "normal" perfectionism, } \\
\text { which are distinguished by scientists }\end{array}$ \\
\hline $\begin{array}{ll}\text { Effective perception of } \\
\text { reality and ability } \\
\text { navigate it well }\end{array}$ & $\begin{array}{l}\text { - Active life position, confidence, stress resistance } \\
\text { (A. Zolotareva); } \\
\text { - Ability to accept life changes and navigate life } \\
\text { situations (A. Zolotareva); } \\
\text { - Positive future expectations, pursuit of goals } \\
\text { (A. Zolotareva); } \\
\text { - Differentiated and accurate perception of } \\
\text { expectations and demands by others (N. Garanyan); } \\
\text { - Moderate mobilization of coping resources } \\
\text { with a predominance of active coping strategies } \\
\text { (N. Garanyan); } \\
\text { - Adaptive tactics for choosing moderately difficult } \\
\text { goals (N. Garanyan); } \\
\text { - Change of standards according to the situation } \\
\text { (O. Kashina). }\end{array}$ \\
\hline $\begin{array}{ll}\text { Effective perception } & \text { of } \\
\text { reality and ability } & \text { to } \\
\text { navigate it well } & \end{array}$ & $\begin{array}{l}\text { - Active life position, confidence, stress resistance } \\
\text { (A. Zolotareva); } \\
\text { - The ability to make vital changes to successfully } \\
\text { navigate life situations (A. Zolotarev); } \\
\text { - Positive future expectations, pursuit of goals } \\
\text { (A. Zolotareva); } \\
\text { - Differentiated and accurate perception of } \\
\text { expectations and demands from other people } \\
\text { (N. Garanyan); } \\
\text { - Moderate mobilization of coping resources } \\
\text { with a predominance of active coping strategies } \\
\text { (N. Garanyan); } \\
\text { - Adaptive tactics for choosing moderately difficult } \\
\text { goals (N. Garanyan); } \\
\text { - Change of standards according to the situation } \\
\text { (O. Kashina). }\end{array}$ \\
\hline
\end{tabular}


Table 1 (ending)

\begin{tabular}{|c|c|}
\hline $\begin{array}{c}\text { Criteria for self- } \\
\text { actualized personalities } \\
\text { by A. Maslow }\end{array}$ & $\begin{array}{l}\text { Criteria for "normal" perfectionism, } \\
\text { which are distinguished by scientists }\end{array}$ \\
\hline $\begin{array}{l}\text { Acceptance (of } \\
\text { themselves, of others, of } \\
\text { nature) as they are }\end{array}$ & $\begin{array}{l}\text { - Experience of self-identity, recognition and } \\
\text { acceptance of one's own resources and limitations } \\
\text { (A. Zolotareva); } \\
\text { - Willingness to take risks in case of probable } \\
\text { failure (A. Zolotareva); } \\
\text { - Perception of failures as potential opportunities, } \\
\text { search for new ways of solving the problem } \\
\text { (A. Zolotareva); } \\
\text { - Developed ability to decentralize, realistic ideas } \\
\text { about the range of human opportunities } \\
\text { (N. Garanyan); } \\
\text { - Perceptions of both success and failure, awareness } \\
\text { of the inevitability and usefulness of mistakes } \\
\text { (N. Garanyan); } \\
\text { - Graded ideas about the results of their activities } \\
\text { (N. Garanyan). }\end{array}$ \\
\hline $\begin{array}{l}\text { Suddenness, simplicity, } \\
\text { naturalness in expression } \\
\text { of thoughts and feelings, } \\
\text { independence in views }\end{array}$ & $\begin{array}{l}\text { - Independence and orientation to one's own } \\
\text { standards, confidence in the choice of a life path } \\
\text { (A. Zolotareva); } \\
\text { - Calm but meticulous attitude towards the } \\
\text { activities performed (A.P. Kashina). }\end{array}$ \\
\hline $\begin{array}{l}\text { Will and activity; } \\
\text { Cheerfulness; } \\
\text { Enjoying any activity }\end{array}$ & $\begin{array}{l}\text { - Experience of happiness, meaningfulness and } \\
\text { satisfaction with life (A. Zolotareva); } \\
\text { - Personal growth and sense of continuous self- } \\
\text { development, self-perfection and realization of one's } \\
\text { potential (A. Zolotarev); } \\
\text { - Feeling full of energy and life (A. Zolotareva); } \\
\text { - Ability to enjoy activity (O. Kashina); } \\
\text { - Enjoyment of activity, hope for success, moderate } \\
\text { stress resistance in daily life (N. Garanyan). }\end{array}$ \\
\hline $\begin{array}{l}\text { Identification } r \text { with } \\
\text { humanity is a deep } \\
\text { experience of oneness } \\
\text { with other people. }\end{array}$ & $\begin{array}{l}\text { - The goals are achieved for the sake of the welfare } \\
\text { of society (O.P. Kashina). }\end{array}$ \\
\hline
\end{tabular}

Based on Table 1, it can be summarize that the distinguished characteristics of "normal" perfectionism and self-actualization reflect virtually the same essence in a person's desire for excellence. We adhere to the position that perfectionism should not be divided into positive and negative, as two different ways (consequences) of striving for selfimprovement. After all, in this case, "normal" perfectionism is almost 
equated with self-actualization, and the criteria of isolation of one and the other are blurred, although it is not the same.

We define perfectionism as a holistic phenomenon in which both functional and dysfunctional aspects are presented, which differ only in the levels of manifestation, which should not be distinguished, Fig. 1. and it can be called extrapsychic and intrapsychic levels. Consider and explain them.

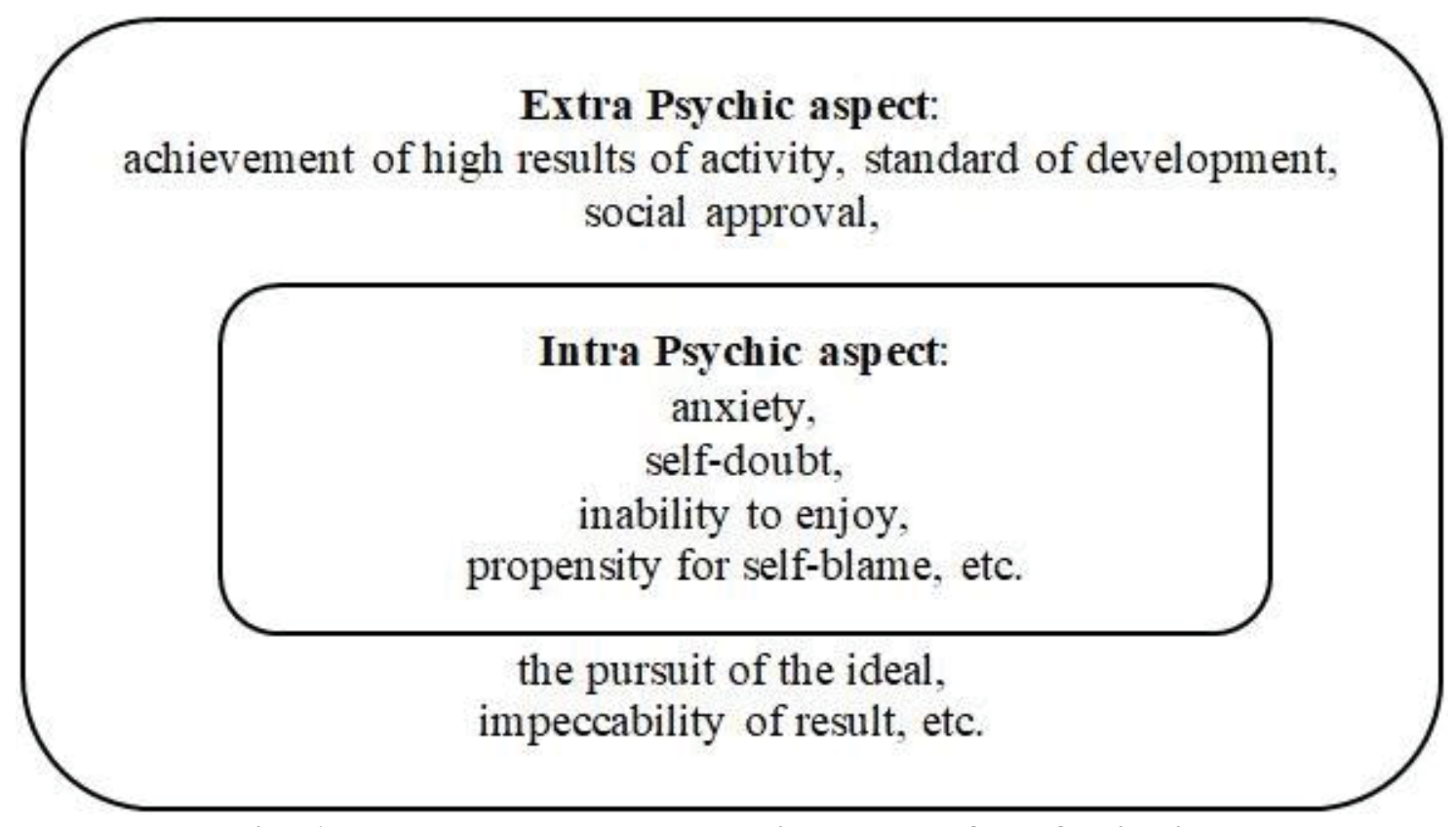

Fig. 1. Extra- and Intra Psychic aspets of perfectionism

Extra Psychic (or external) aspect reflects the social encouragement, recognition and advocacy of achieving high performance. It represents an external, positive aspect. After all, perfectionism is a prosocial behavior. The social environment actively promotes, stimulates and encourages to achieve perfection. People who have achieved high results of activity set an example for others, they are admired, such personalities set standards and ideals, the level to which others should strive.

Intra Psychic (or intrapersonal) aspect is represented by those intrinsic psychological problems that arise in the individual in the pursuit of perfect performance. These are constant doubts about the correctness of their actions, fear of criticism, inability to get pleasure from the results of activity, feelings of helplessness, unproductiveness, anxiety, etc.

Thus, perfectionism combines two sides, two aspects that can exert both a functional influence on the personality and a dysfunctional one, which are inseparable and interconnected.

What is the difference between perfectionist and self-actualized personality? The analysis of theoretical and practical researches gives rise to the development of the author's scheme, which is presented in fig. 2. 


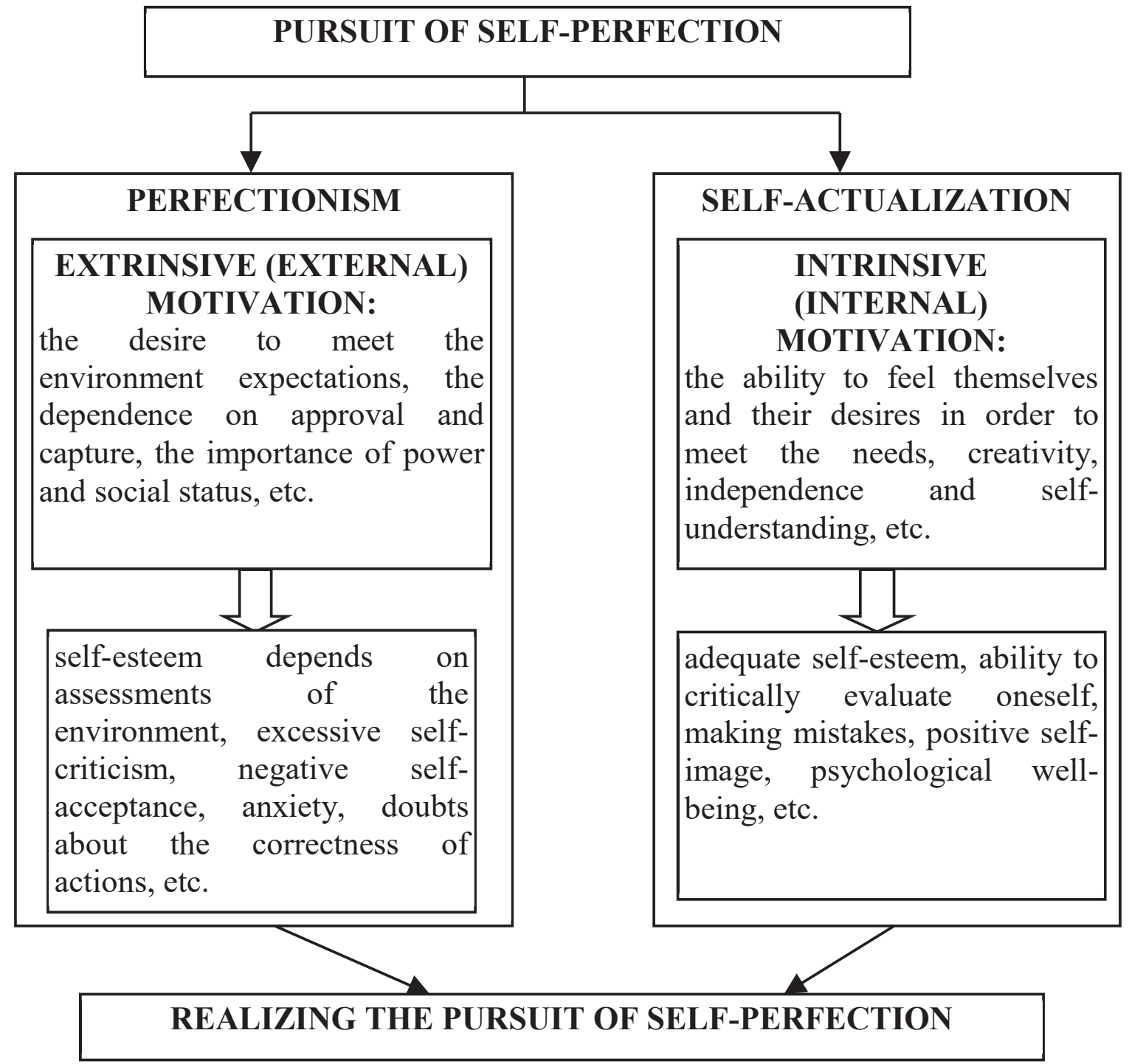

Fig. 2. The scheme of differences between the manifestation of perfectionism and self-actualization of the individual

The main criterion of this scheme is the choice of one type of motivation - extrinsic (external) or intrinsic (internal) - why does a person perform activity or occupation? Both choices, provided the desire for self-improvement, promotes active behavior for self-realization, however, internally distinguished by the presence or absence of psychological equilibrium, confidence and satisfaction.

Thus, if self-actualization acts as a process of revealing one's own capacities, which promotes internal harmonization and effective functioning in society and is more connected with reliance on one's Self, one's resources and beliefs. That is, perfectionism is more oriented towards external standards and norms, and conviction that perfection in any way is to be achieved (in all important areas of life). This position contributes to the continued dissatisfaction with the results of the activities related to selfcriticism, dependence on the positive evaluation of people. 


\section{CONCLUSIONS}

1. The study of perfectionism in the psychological plane is analyzed. The basic approaches and models of perfectionism are also presented.

2. Perfectionism is defined as a personality trait, which is the pursuit of excellence, the imposition of high demands and unrealistic standards, which, on the one hand, has a social context and expressive social determination, is cultivated by modern society and foresees social promotion and recognition, protection, on the other - associated with a number of dysfunctional features (cognitive, emotional, behavioral). It is a holistic socio-psychological phenomenon that combines both positive (extrapsychic) and negative (intrapsychic) aspects.

3. The desire for self-improvement can be realized both through extrinsic and intrinsic motivation, in which perfectionism is presented through the prism of the first, self-actualization is the second one. Perfectionism is characterised by an extrinsic (external) motivation, which is reflected in the desire to satisfy the environment expectations, dependence on the approval and admiration of others, the importance of power and social status.

4. The common and distinguishing features between perfectionism and pedantry are distinguished. Increased anxiety; rigidity, inflexibility; prolonged experience of traumatic situations; excessive honesty; doubts about the correctness of their actions are common to perfectionism and pedantry. The differences between pedantry and perfectionism are the following: 1. Form is more important than content for a pedantic personality, but perfectionists are more fixed in content or, more precisely, in result. 2. Perfectionists try to reach the ideal in substantial affairs, pedants - in small ones. 3. The perfectionist's assessment of the results of his/her own activity depends on external factors, and pedants evaluate their work in accordance with their own (internal) beliefs, positions. 4. Pedants are more conservative than perfectionists.

5. The prospect of further research is seen in the study of sociopsychological factors that cause the manifestation of perfectionism, as well as the study of the features of self-regulation of perfectionists.

\section{SUMMARY}

The article is devoted to the theoretical analysis of perfectionism as a psychological phenomenon. In particular, the problem of isolation of positive and negative (adaptive/maladaptive; functionaldysfunctional; healthy/pathological) types of perfectionism offered by scientists in the psychological literature is analyzed. It is suggested to abandon the division of perfectionism into its forms, and to consider perfectionism as a holistic phenomenon in which there are always two sides: extrapsychic and intrapsychic aspects. Extrapsychic aspect is represented by social 
encouragement and recognition of perfectionist tendencies, and intrapsychic - by dysfunctional features (emotional, cognitive and behavioral), manifested in chronic discomfort, constant doubts about their own actions, uncertainty, anxiety, poor performance, etc.

It is also presented that the realization of one's own achievements can be manifested both through perfectionism (achievement of high performance, striving for excellence, at the same time, desire to satisfy expectations of the environment, dependence on approval and admiration, importance of power and social status, etc.), and through self-actualization (the ability to feel themselves and their desires to meet needs, creativity, independence and self-understanding, etc.).

The theoretical analysis of the common and different in the psychological concepts: "perfectionism" and "pedantry" is also made.

\section{REFERENCES}

1. Maslow A. Motivation and personality. New York : Harper and Row, 1987.

2. Freud S. A general intodaction of psychoanalysis. New York : Boni and Liveright, 1920.

3. Jung, C.G. On the Nature of the Psyche. London : Ark Paperbacks, 1947.

4. Adler A. Understanding Human Nature, Oxford : Oneworld, 1927 (reprinted 1992).

5. Horney K. The neurotic personality of our time, New Haven, CT : Yale Univesity Press, 1999.

6. Horney K. Our inner conflicts. New York : N.orton, 1945.

7. Hollender M. Perfectionism. Comprehensive Psychiatry. V. 6. 1965. P. 94-103. doi: 10.1016/s0010-440x(65)80016-5

8. Burns D. The perfectionist's script for self-defeat. Psychology Today. 1980. P. 34-52.

9. Frost R., Marten P., Lahart C., Rosenblate R. Cognitive Therapy and Research. 1990. № 14 (5). P. 449-468. doi.org/10.1007/BF01172967.

10. Hewitt P., Flett G. Perfectionism in the Self and Social context: conceptualization, assessement and association with psychopathology. Journal of Personality and Social Psychology. 1991. V. 60. № 3. P. 456-470. doi:10.1037/0022-3514.60.3.456.

11. Гаранян Н.Г. Психологические модели перфекционизма. Вопросы психологии. 2009. № 5. С. 74-83.

12. Гуляс I.А. Перфекціоністські настанови як чинник професійної готовності майбутніх практичних психологів : автореф. дис. ... канд. псих. наук. Івано-Франківськ, 2007. 21 с. 
13. Данилевич Л.А. Перфекціонізм як особистий чинник академічної обдарованості студентів : дис. ... канд. псих. наук. Київ, 2010. $240 \mathrm{c}$.

14. Лоза О.О. Особливості перфекціонізму як особистісної риси державних службовців : дис. ... канд. псих. наук. Київ, 2015. 205 с.

15. Hamachek D. Psychodynamics of normal and neurotic perfectionism. Psychology. 1978. № 15. P. 27-33.

16. Parker W., Adkins K. Perfectionism and the gifted. Roeper Review. 1995. V. 17. № 3. P. 173-176.

17. Rice K., Ashby J., Slaney R. Self-esteem as a mediator between perfectionism and depression: A structural equation analysis. Journal of Counseling Psychology. 1998. V. 45. № 3. P. 304-314. https://doi.org/10.1037/0022-0167.45.3.304

18. Холмогорова А., Гаранян Н. Нарцисизм, перфекционизм и депрессия. Московский психотерапевтический журнал. 2004. № 4. C. $18-35$.

19. Золотарева А.А. Диагностика индивидуальных различий перфекционизма личности : автореф. дис. ... канд. псих. наук : 19.00.01. Москва, 2012. 25 с.

20. Ганнушкин П.Б. Клиника психопатий, их статика, динамика, систематика. Москва : НГМА, 1998. 122 с.

21. Shimoda M. Uber den pramorbiden Charakter des manischdepressiven Irreseins. Psychiat. Neurol. Jap. 1941. № 45. P. 101-102.

22. Tellenbach H. Melancholie. Problemgeschichte Endogenitat Typologie Pathogenese Klinik. New York : Springer-Verlag BerlinHeidelberg, 1983. $201 \mathrm{p}$.

23. Соколова Е.T. Психология нарциссизма. Москва : «Психология», 2001.90 с.

24. Burns D. The feeling good handbook. New York : William Morrow and Company, 1989. $121 \mathrm{p}$.

25. Blatt S.J. The destructiveness of perfectionism. American Psychologist. 1995. V. 50. P. 1003-1020.

26. Frost R. Reactions to mistakes among subjects high and low in perfectionistic concern over mistakes. Cognitive Therapy and Research. 1995. V. 19. P. 195-205.

27. Юдеева Т.Ю. Перфекционизм как личностный фактор депрессивных и тревожных расстройств : дис. ... канд. псих. наук. Москва, 2007. 275 с.

28. Shafran R., Mansell W. Perfectionism and psychopathology: a review of research and treatment. Clinical Psychology Review. 2001. № 21. P. 879-903. DOI: 10.1016/S0272-7358(00)00072-6. 
29. Бескова Т.В. Взаимосвязь перфекционизма со способами реагирования на успех и неудачу другого. Современные проблемы науки и образования. 2012.

30. Гаранян Н., Андрусенко Д., Хломов И. Перфекционизм как фактор студенческой дезадаптации. Психологическая наука $u$ образование. 2009. № 1. С. 72-82.

31. Цыганкова П.В. Взаимосвязь перфекционизма с особенностями самосознания при аутодеструктивном поведении. Вестник Московского государственного областного университета. Серия «Психологические науки». 2010. № 2. С. 28-32.

32. Парамонова В.В. Высшие устремления личности: перфекционизм как патологический феномен. Развитие личности. 2009. № 1. C. 64-78.

33. Савенков А.И. Путь к одаренности: исследовательское поведение дошкольников. Санкт-Петербург : Питер, 2004. 272 с.

Information about the author: Zavada T. Yu.,

Ph.D. in General Psychology, Lecturer at the Department of Psychology and Psychotherapy Ukrainian Catholic University 17, Sventsitskoho str., Lviv, Ukraine 